Santa Clara University

Scholar Commons

Economics

Leavey School of Business

4-16-1998

\title{
Extra-Household Norms and Intra-Household Bargaining: Gender in Sudan and Burkina Faso
}

Michael Kevane

SantaClara University, mkevane@scu.edu

Follow this and additional works at: http://scholarcommons.scu.edu/econ

Part of the Economics Commons, and the Feminist, Gender, and Sexuality Studies Commons

\section{Recommended Citation}

Kevane, Michael, Extra-Household Norms and Intra-Household Bargaining: Gender in Sudan and Burkina Faso (April 16, 1998). Available at SSRN: http://ssrn.com/abstract=1115509 or http://dx.doi.org/10.2139/ssrn.1115509 
Preliminary draft

Comments welcome

April 16, 1998

Extra-household Norms and Intra-household Bargaining:

Gender in Sudan and Burkina Faso

\author{
Michael Kevane \\ Department of Economics \\ Santa Clara University \\ Santa Clara, CA 95053 \\ mkevane@mailer.scu.edu \\ 408-554-6888
}

\begin{abstract}
This paper argues that future empirical strategies for approaching the problem of deepening relative poverty for women in sub-Saharan Africa might focus on distinguishing and weighing two complementary determinants of the process. One determinant is the changing distribution of intra-household bargaining power. The other determinant is the changing constellation of social norms that constrain and regulate the economic activities of women. The paper shows how fruitful this dichotomization may be in the context of an analysis of women's economic activities in western Sudan and south-western Burkina Faso. In western Sudan the military regime deliberately brought about changes, at the very local level, in norms regarding proper activities for women in the marketplace. In Burkina Faso, a detailed study of time allocation shows that women in different ethnic groups face quite different norms regarding the obligation to work for their husbands. Both of the case studies suggest that analysis and policy that takes into account the societal level norms regarding women's activities may be more important than analysis and policy that focuses on intra-household processes alone.
\end{abstract}




\section{Extra-household Norms and Intra-household Bargaining: \\ Gender in Sudan and Burkina Faso}

\section{Michael Kevane}

\section{Introduction}

The hypothesis that the ongoing commercialization of agriculture in sub-Saharan Africa may be leading to a relative impoverishment of women is asserted on the basis many sources: anecdotal material; small-sample, single-country surveys; meta-analysis of those surveys; and creative interpretation of unreliable national-level statistics. ${ }^{1}$ In the absence of large-scale representative samples of households and individuals across the continent, the assertion must remain unverifiable. But it is important enough to merit serious theorizing, both in an effort to guide policy and to influence the design of further data-collection efforts. Future empirical strategies for approaching the problem might productively focus on distinguishing and weighing two complementary determinants of the changing fortunes of women. ${ }^{2}$ One determinant is the changing distribution of intra-household bargaining power. The other determinant is the changing constellation of social norms that constrain and regulate the economic activities of women. This chapter focuses on the second, showing how important social norms may be in the understanding women's economic activities in western Sudan and south-western Burkina Faso.

Carney's and Watts' (1990) discussion of an irrigation project in Gambia nicely illustrates the differences between the two determinants. The authors suggest that the net effect of the project was a worsening of the position of women. Men expropriated land previously controlled 
by women, and extracted more labor surplus. But did this negative effect happen because husbands, now granted title to more valuable land, were able to strengthen their bargaining positions against their wives? Or did it happen because men, now granted title to more valuable land, were able to strengthen their bargaining positions against women? The differencewhether the change is within the household or without the household — is fundamental. The literature sometimes labels these two approaches the 'intra-household' and 'extra-household' approaches. ${ }^{3}$

Social norms that are generated and maintained at the extra-household level have two distinct ways of affecting economic activities. An indirect way is by affecting the bargaining that goes on within households. Norms may influence the 'threat points' and processes of intrahousehold bargaining. Agarwal (1997:15-22) notes that extra-household norms influence intrahousehold bargaining by changing the 'inside' and 'outside' options available to wives in the event of disagreement. Norms regarding childcare, divorce, bridewealth, remarriage, wife-beating, and family responsibilities to daughters will change threat points. Changes in these norms make the threats of women to leave their household or not cooperate with their husband more or less credible. Norms may also regulate the nature of bargaining. For example, norms may call for silent acquiescence for women when men display anger; that is, norms may determine who has the right to initiate or terminate bargaining.

But norms may also directly prescribe and proscribe certain activities for women; they are 'activity-regulating.' The effects of activity-regulating social norms may be quite significant. Women may be excluded from certain kinds of jobs or tasks, perhaps the more lucrative ones. Women may be prohibited from exploiting certain specific common-property resources such as 
wildlife or forests. Women may be denied the right to interact with state officials and secure the rents distributed by official credit, work, and extension programs. Activity-regulating social norms will also influence the distribution of bargaining power within households; but even if women were not in households, or if households were characterized by shared preferences, they would still be affected by activity-regulating norms.

Both the distribution of intra-household bargaining power and the constellation of activityregulating social norms vary with prices and technologies. In the intra-household bargaining approach, a standard result applies: changes in prices or technologies that alter options (either the options of leaving the marriage or continuing in the marriage but not cooperating with the husband-- a kind of one-person strike) will affect the decisions and actions men and women make. If changes in the external environment benefit men, they will be in stronger bargaining positions. For example, improvements in the prices of agricultural products benefit the owners of land; if land owners always happen to be men, then men are now in stronger bargaining positions. Many development projects for women are based on the assumption that access to credit or outside income will raise the bargaining power of women within the household.

The theory of how social norms change in response to commercialization and associated changes in prices and technologies is comparatively under-developed. While it is now generally recognized that norms are endogenous, just how they might change is an open question. Some researchers favor an evolutionary modeling approach, arguing that norms change in an 'unconscious' way as individuals holding on to less 'fit' norms suffer economically (Young 1998). Others adopt threshold models of norms, where equilibrium strategies suddenly change when a tipping point is reached with sufficient critical mass adopting a new strategy. The changes in 
strategies are quite deliberate choices of individuals, but they are made in a decentralized manner. A recent paper by Akerlof, Yellen and Katz (1996) offers a straightforward model along these lines, and will be discussed below. A third approach suggests that new norms- or ideologies-are generated as the bargaining power of social groups change (Grundfest Schoepf 1985; Folbre 1997; and Ensminger and Knight 1997). There is implicitly some level of social cooperation, group cohesion and coordination, or collusion in this process.

Figure 1 schematizes this discussion of how these two important social arenas determine women's agricultural activities. Prices and technologies affect both intra-household bargaining and extra-household negotiations or decentralized emergence of new norms. Extra-household norms affect intra-household bargaining. Intra-household bargaining in turn affects the choices made at the extra-household level; changes in the distribution of power within households may undermine the collective bargaining position of women in negotiating extra-household norms (see Carter and Katz 1997).

The distinction between intra-household bargaining and extra-household norms regulating economic activities is quite relevant for an analysis of women's involvement in commercial activities in western Sudan and southwestern Burkina Faso. In both of these regions, agriculture is highly commercialized: farmers of western Sudan grow groundnuts and sesame primarily for the markets, while farmers in Burkina Faso grow cotton for export. There has been increasing investment in market gardens and orchards (particularly in mango) irrigated by hand or small pumps. Burkina Faso has seen the introduction and adoption of animal traction and motorized and un-motorized personal transportation (mobilettes and bicycles). Cotton extension is widespread, and with it use of imported pesticides and fertilizers. Western Sudan has seen little 
change in the tools used in production, with virtually all farmers continuing to use the longhandled hoe (hashasha).

Both areas have seen significant expansion of the non-agricultural economy, consisting of small-scale food processing, petty trade and local handicrafts. Women in western Sudan have been active in establishing small restaurants and tea stands. Women knit and embroider small prayer caps and clothing. In Burkina Faso, beer brewing is an important activity for many women. Processing of butter from the oil of the karite nut, and processing as a condiment the pods from the néré tree, are other common activities oriented towards the market. In some areas considerable specialization of these tasks has taken place, with women in a village specializing in a particular stage in the processing. Extensive rural networks of traders have arisen to bring the products to higher stage users, or even to export markets (Saul 1981). Despite the changes in Burkina Faso, incomes remain low and uncertain. Incomes in rural western Sudan are certainly among the lowest in the world.

The purpose of this chapter is to present evidence that extra-household activity-regulating social norms matter a great deal in determining women's involvement in agriculture and other economic activities. The chapter shows that the norms regulating activities vary considerably across ethnic groups and change over time. The inter-ethnic differences in norms, and government-induced changes over time, are both seen to have large effects on behavior. In western Sudan, the military regime backed by the National Islamic Front has embarked on a campaign to exclude women from the lucrative sales of tea and processed food in market spaces. In Burkina Faso, Mossi and Bwa villagers occupying the same area have quite different norms and 
behaviors. The changes and differences in norms, and the subsequent effects, are different from changes and differences in the distribution of intra-household bargaining power.

The paper proceeds as follows. First, the literature that assesses the intra-household approach with data and research from the Sahel area of sub-Saharan Africa is reviewed. Second, this is followed by a discussion of the notion of extra-household norms. Third, how activityregulating social norms may be analyzed in the context of sub-Saharan Africa is considered. Fourth, these distinctions are applied to the context of western Sudan, where the military regime has tried to directly alter the activity-regulating social norms, followed by an examination of the differences in gendered norms across two ethnic groups in Burkina Faso, showing that the more patriarchal Mossi do seem to have stronger norms regulating economic activity than the less restrictive Bwa. Finally the conclusion deals with some implications for policy.

The intra-household approach

The recent collection of papers edited by Haddad, Hoddinott and Alderman (1997) summarizes some of the major work and ideas produced by the intra-household approach. The approach draws on analysis initiated by the game-theoretic models of the household. This view sees men and women in 'cooperative conflict' within the household: on the one hand they are engaged in the production of public goods (like children and a sense of family and home) characterized by 'team' production processes where it is hard to determine the value of the marginal product of individual contribution; on the other hand, they each want to obtain consumption or prestige goods for themselves or for children they care about. So the interests of 
household members converge and diverge at the same time. An appropriate way to model these kinds of situations is by using models of bargaining.

The empirical literature on households has confirmed that households are generally not characterized as having a single altruistic or dictatorial head, or even as having shared preferences. In that view, often termed the 'unitary model,' men and women's time and income are allocated according to comparative advantage. Instead of efficient allocation, however, it seems there is considerable leeway in the abilities of women and children to exert bargaining power and make choices. ${ }^{4}$ The process of determining the allocation of labor and income and the adoption of technologies is thus not one-sided, or the result of a 'unitary' joint family decision process. Households are 'contested terrains.' Guyer (1988:160), for instance, concludes that: The assumption that the domestic group is a tightly functional unity of the kind put forward in Becker's recent theoretical work (1981) is untenable, even at the straighforwardly descriptive level. It matters who gains control of output because men and women have different spending preferences, not necessarily because they hold different values but because they are in structurally different situations.

One way researchers prove wrong the 'unitary' model is by showing that women allocate their labor and capital toward activities that put income under their direct control even if it is not efficient. Von Braun and Webb (1989), following upon earlier work by Ram and Singh (1988) and Jones (1986), find that gross margins (value minus variable input costs except for unpaid land and labor, per day of unpaid labor) on male-controlled communal plots are typically double those of 'private' female plots in Gambia. Udry (1996) demonstrates that in a panel sample from 
Burkina Faso, the yields on women's fields are lower than on men's fields, controlling for year, plot and household specific effects. Extensive specification testing rules out most of the usual candidates for reconciling this finding with household allocative efficiency: women's plots are not of inferior quality; women are not overly constrained by child 'rearing' duties; women's plots are not treated differently because of fixed 'travel' costs; and the technology does not appear to differ across men and women. Findings of differences in yields are signs of inefficiency within households. Simply reallocating labor and manure to the women's fields (small as they might be) would generate higher income for the household. Why not do that, and divide up the extra production? The findings imply that households are not 'unitary,' but rather are characterized by bargaining.

In a bargaining framework, it is expected that men and women allocate their resources in ways that raise their 'threat points.' If a woman ceded control of her land and labor to her husband, she would have no credible threat if he failed to give her consumption goods. Women maintain flexibility within the conjugal unit by reserving part of their labor for their own land. Productivity differences arise because the conjugal unit more closely resembles a contractual, bargained relationship than a 'family' maximizing common welfare (Quisumbing 1996).

Another way of proving wrong the 'unitary' model is to show that allocations and inefficiencies vary across households in ways predicted by the intra-household bargaining approach, but not by the comparative advantage approach. Some researchers have examined what factors make unequal rights between men and women matter more or less for individual women. Saul (1989) asks how different Bobo women from Burkina Faso are affected by and manipulate the margins and ambiguities of limited land use rights. He shows that patterns of 
activity are more or less binding according to factors such as wealth and age that influence bargaining within households and lineages. Age frequently determines the autonomy that women have in their allocation of time, and Saul (1989:173) describes how women go "through successive stages of increasing autonomy during their lifetime." Older women and widows often have a wider choice of crops to plant, hours they can work, and land which they can cultivate. They often 'separate' from the household, in stark contrast to the comparative advantage approach which would suggest that as a woman gets older the 'human capital' she builds up regarding the household enterprise would make it advantageous for her to be more, not less, involved in the household. Saul points out that the entire range of women's activities- not just farmwork- is determined by the intra-household bargaining among a man and his wives and among co-wives.

It should not be surprising that when household decisions are the results of bargaining, major transformations such as the deepening and extension of commercial relations with global markets, development projects, and technological innovations have highly variable impacts. Thus Bassett (1988) argues that the introduction of cotton in Cote d'Ivoire led to a rapid intensification of agriculture and increased time devoted to household production. The increase in labor time was borne by both men and women, but there was an apparent deterioration in the position of women who ended up forming 90 percent of the hired wage labor force. As Bassett (1991:23334) makes clear, the extensification of cotton was partly led by provision of subsidized cotton inputs that were directly almost exclusively to men. Jones (1986), however, finds that in Cameroon there was less intensification following the introduction of irrigation that permitted rice growing. The division of the increased surplus could not always be negotiated. Some women 
acquiesced to the increased demands for labor from their husbands, but many simply refused to devote large amounts of time to rice production. These women withdrew from household production activities and concentrated on their own, separate, sorghum plots, or worked as wage laborers.

Activity-regulating norms in sub-Saharan Africa

Changes in the distribution of power within households, and the subsequent reorganizations of work and rewards, are not the only mechanism through which external changes like increased commercialization affect the welfare of women. Women may be subject to social norms that bind and determine their actions (Obbo 1976; Roberts 1984; Roberts 1988). These norms are negotiated and replicated at the extra-household level. Implicit marriage contracts may contain agreements that women will work a specific amount of time on the fields of their husbands. More generally, women may not have control over their labor, and be ostracized if they try to work off the farm. Women's ownership rights to plots obtained through inheritance and marriage may be tenuous. A man may refuse to lend money to a woman, fearing that no court will enforce repayment. There may be taboos against women handling manure. In many areas of northern Nigeria, women among the Muslim Hausa ethnic group are forbidden from working in public labor markets, either in the village or out in the fields. This prohibition is known as kulle, which Hill (1969:398) refers to as a 'virtual incarceration' (see alsoSolivetti 1994). Turrittin (1988) notes the growing importance Wahhabism, an Islamic sect spreading rapidly in Mali, in fostering stricter norms about women's activities outside of the home. 
The literature analyzing these activity-regulating norms has argued that gendered norms may in fact be the outcome of gender contests. That is, researchers have tried to show that in certain contexts it is proper to speak of men and women as antagonists in the public negotiations over social norms and institutions (despite most men and women sharing households, with the important exception of sometimes significant numbers of female-headed households). Folbre (1986:21) suggests that, "neoclassical institutionalists, like conventional Marxists, have largely ignored the possibility that men might develop and defend institutional forms of power in a systematic way." Folbre (1997) has more recently articulated exactly what these negotiations are about, using the phrase 'gender coalitions' to make explicit the idea that men and women may indeed bargain collectively. In the context of sub-Saharan Africa, Saul (1989:174) describes the issue clearly: "The possibility of the formation of gender blocs dividing all production units right in the middle should not be underestimated; in protest movements or rituals of reversal [such as the Nigerian 'Sitting on a Man' case] such blocs manifest a strikingly physical reality.” The literature has a wealth of anecdotes detailing exactly this possibility. A recent collection of papers in the Canadian Journal of African Studies, introduced by Hodgson and McCurdy (1996), offers numerous accounts of this social negotiation over legitimate activities of women.

Social norms and collective action appear to be quite important. Carney and Watts (1990) argue that the Jahaly-Pacharr Gambian irrigation project, the latest in a series of interventions designed to reduce rice imports, provoked unexpected kinds of conflicts. The particular external production relations were 'inflected inward' to the conjugal unit, rather than expressed 'outward' as in earlier instances of peasant resistance. Struggles over meaning permeated household relations; norms were renegotiated and changed (ibid.: 228): "As a consequence women have 
withdrawn their labor from the rice fields, an explosive tactic with far-reaching impact on the social organization of household production." Von Bulow (1992:538), discusses how in Kenya tea areas, women similarly refused to pick tea following changes in external factors; they withdrew their labor from their husbands. Comparatively low yields and increases in wage labor were the outcomes of these struggles over activity-regulating norms.

\section{A model of activity-regulating norms}

Commercialization of agriculture, through the continuing introduction of new crops or through changes in relative prices on global markets that encourage specialization in exportoriented or urban-oriented production, may affect activity-regulating norms. To understand how, it is necessary to be more specific on exactly what norms are. One approach is to define a norm is a regularity in the strategies that people follow when they are in strategic situations (when the consequences of their choices depend directly on the choices of others). The regularity is created by the expectation that others too follow the same regularity. A norm in this definition is a convention, and one follows a convention because breaking the convention risks undermining the convention itself. Since the convention yields benefits, the convention is sustained when the benefits (discounted over a lifetime) outweigh the benefits of breaking the convention and living the remainder of one's life without the convention. An extension of this approach is to define a norm as a regularity in strategic behavior sustained by sanctions against violators. This is a stronger definition than the first because now the costs of the norm may outweigh the benefits, but the costs of breaking the norm are endogenously higher; in addition to having some interest in 
abiding by the convention for the benefits of the convention itself, people also want to avoid explicit punishment for violating the convention.

With this understanding of norms, consider a stylized model, introduced into the literature by Akerlof, Yellen and Katz (1996), which may be adapted to a sub-Saharan setting. In this model, men and women have to decide whether or not to agree to marry. The problem for a man is that he can only marry a finite number of times (for simplicity assume it is once). He would like to marry a wife who will be cooperative in working on the family enterprise. That is, the man is like an employer, and has only so many chances to hire an employee. He certainly does not want a wife/employee who will spend most of her time off on her own activities. So the man may want to extract a promise from the potential wife that she will work for him, and not spend much of her time on her own income-generating activities. The woman, of course, would much rather not make such a promise: who knows whether her husband will pay her well for work she does on his family enterprise? When asking for a promise not to work on self-owned income-generating activities, the man risks that the woman will simply refuse, and go try her luck in the marriage 'market' with another potential partner.

Promises are assumed to be enforceable — the wife cannot renege on the promise. The man has to decide whether to request such a promise and risk having the woman refuse.

[Figure 2 about here]

Figure 2 shows the structure of the game that men and women play as they decide whether to marry a particular person. The man has the first decision of whether to insist that the woman must work for him if they marry. If the man does not insist, the woman of course marries (men are assumed identical in all other respects). She can do no better by waiting. Her net payoff 
is given by $r_{f}-p_{f}$, with $r_{f}$ the benefits and $p_{f}$ the costs of marriage. The net payoff is assumed positive. If the man insists that she work for him, and she agrees to be married under this condition, her payoff is $r_{f}-p_{f}-d_{f}$, where $d_{f}$ is the cost of not allocating her time optimally, but rather having the husband control some significant amount of her time.

The man gets a benefit $r_{m}$ from marriage, but this comes at a cost. The cost of marriage is being tied down, as it were, by wife and child and hence foregoing opportunities for entrepreneurship. Men, for whatever reasons, are the only people who can be entrepreneurs and take advantage of new activities. Perhaps only they have access to capital markets. The cost of foregoing entrepreneurship is $\mathrm{p}_{\mathrm{m}}$. When the wife works for the man, part of this cost is offset by the advantage of having ready labor at hand, and this is represented by $\mathrm{d}_{\mathrm{m}}$. So the man's net benefit when marrying with a promise from the woman that she will work for him is $r_{m}-p_{m}+d_{m}$.

In this situation, the man's best strategy depends crucially on what he thinks other men are doing. If all other men demand that women work for them, then the man will also make such a demand. Why? Because if his potential wife refuses, and goes off to consider other men, she will find they are all making the same demand, so she may as well have accepted the initial offer with its demand of a promise to work. Forseeing this, she will indeed accept a demand that the man control her time. If, on the other hand, few men demand such promises, then the equilibrium strategy for the man may be to also not demand that the woman work for him after marriage.

In this structure, a norm is an equilibrium where people are observed following similar strategies because they assume that other people will follow the same strategy. The norm may change if any of the payoffs change. Suppose, for instance, that the initial equilibrium is one where men and women marry without any promises that oblige the woman to work for the man. 
It may then arise that increasing commercialization raises, for entrepreneurial men, the opportunity cost of being married. This leads them to demand that their future wives work for them. Other men, who may have no intentions of being entrepreneurs, 'piggyback' off the demands made by the entrepreneurs. If the entrepreneurs constitute a significant fraction of the population, then all men will demand promises that the women work for them. A change that affects a fraction of men-- those entrepreneurs who could take advantage of new commercial opportunities - potentially impoverishes all women.

A norm that men insist that their future spouses work for them may come to be sustained by sanctions. If a man were to marry and allow his wife to do as she pleases, he might find himself harassed, ostracized and boycotted by other men. Then, the demands of men that their wives work for them may continue to characterize the marriage 'market' even after changes in prices or technologies that favor the independent activities of women. An inefficient norm may well persist (Akerlof 1980). So women may continue to be relatively impoverished even as the tide of commercialization turns in their favor, as demand for market processing and trading grows.

The clearest example of this kind of process comes from Kenya, where Hakannson (1986) documented the changing fortunes of Gusii women. At one time a woman marrying was entitled to ownership or at least clear control over house property. Over the 1970s and 1980s, however, men increasingly refused to honor this right; they were insisting on marrying outside the traditional customs. ${ }^{5}$ Men seemed to want more flexibility in the matter of disposing of their land. The new 'elopement' marriage came with no implicit right to property. As more and more men demanded this advantageous form of marriage, women either reluctantly agreed or else refused 
marriage propositions in the hopes of finally attracting a suitor willing to marry under the old terms. As more men demanded the advantageous marriage, the chance of finding other men fell, and women came to accept the new terms. This, of course, made men even less willing to offer the old terms; they knew they could easily find a woman willing to marry the new way.

Activity-regulating norms in western Sudan

A dramatic instance of changing local norms regarding permissible economic activity by women occurred in Bireka, a small village in western Sudan, during the period 1991-1992. In 1989 the National Islamic Front (NIF) took power in Sudan through a military coup. One of the principal policies of the new regime in Khartoum was to regulate the economic activities of women. ${ }^{6}$ The regime focused in particular on restricting women's tea-brewing and beer-brewing activities. (In 1997 the government acknowledged that its strategy had perhaps gone too far, and released over 400 women imprisoned in the capital Khartoum, most of whom had been jailed with small children and infants, for selling tea or brewing beer.) The government had few resources with which to implement its strictures, but it turned out that few were needed. In many villages simmering ethnic, factional, religious and class conflicts were ready, as Carney and Watts (1990) suggested, to be 'inflected' onto the sphere of gender relations. Norms over women's behavior became the battlefield for broader village conflicts. The new ammunition provided by the national-level shift in government power, rhetoric and policy proved sufficient to bring about new norms of behavior, self-enforced, at the village level. ${ }^{7}$

Bireka was in 1990 a village settled by three ethnic groups, and comprising about 50 households. About one fourth of the residents called themselves Arabs, and maintained control 
over formal political structures and claimed ownership over most of the agricultural land in the area. The chief traditional leader for the region, the omda, belonged to the Arab group, and in 1991-92 was given police and judicial powers as part of a program of devolution of authority. Another fourth of the residents were Burgo immigrants from Chad, who settled at roughly the same time as the Arabs at the beginning of the century. The remaining majority of the villagers were Hausa, who settled over the years, some as late as the 1970s or 1980s. Most of the Hausa rented their land on an annual basis, paying only a token sum in advance and then a ten percent share after harvest. All of the villagers pursued diversified activities; the agricultural season was extremely short, and during the dry season many men left for work in other areas of the country. In Bireka, as elsewhere in Sudan, the very dramatic deterioration of the national macroeconomy hastened processes leading to increased specialization, reliance on wage labor work, and breakdown of larger extended families. While these changes before the 1980s impoverished some, they very often improved welfare for farmers and pastoralists. After the 1980s, however, commercialization, where economic activities were increasingly organized through markets, was associated with more general and unambiguous declines in income and welfare (see, among others, Kursany 1983, Tully 1988, Gray and Kevane 1993, and Sultan 1993). Young men increasingly migrated to towns, often leaving their wives and mothers in precarious economic situations (Kevane 1994; Rielly 1991). They left to join the army, or were conscripted into militias, or sought the limited educational opportunities available as the government abandoned (in the face of military costs associated with the civil war) its commitment to rural education. The inter-seasonal prices of sorghum and millet turned against the majority of poor, credit-constrained farmers, who sold in the months after harvest and then had to purchase grain at 
inflated prices during the 'hungry season.' The grain-livestock terms of trade also exacerbated rural incomes, as livestock prices plummeted during years of scarce pastures. These processes led to a feminization of poverty, mitigated only by increased remittance income from men migrating abroad.

In this environment, on 13 October 1991 the following letter was received by the sheikh of Bireka:

To the Sheikh of the village of Bireka:

With regard to the decision issued by the security committee of the district administration, number $46 / 1 / 1 / 1$, on $1 / 8 / 91$, is it declared to the owners (male and female) of coffeehouses $\left[\right.$ gahawi $\left.^{8}\right]$ in Um Belda that they must destroy their buildings and structures by 19/10/91, in order to make it feasible to us to prepare a plan for that area in the future, after the complete clearing of the present structures. We will compel the owners who have not destroyed their buildings by confiscating their furnishings and opening a police complaint against them, so we urge them to complete the clearing of their buildings in the period available. Thank you.

Signed: Inspector of the local government of Sheikan ${ }^{9}$

This letter, ordering the destruction of a thriving roadside market mostly run by women, was the initiation of a rapid process of changing attitudes towards women's work.

In 1990, the roadside was probably the most dynamic sector of the local economy, and it was dominated by women. A large number of younger unmarried Burgo women from Bireka 
operated coffeehouses, tea stands and restaurants. Two older Arab women also had stands; both were very poor women. Many young Arab women from Um Belda, a neighboring village along the road, also operated stands. Young Hausa girls sold sesame candies, roasted groundnuts, and cowpea falafel, known as ta'miya.

Some men profited from the popularity of the women's tea stands. One Hausa household of three brothers operated a stand, often hiring young Arab and Burgo men from Bireka to work for them. The sons of a wealthy local merchant operated, intermittently, a large stand. Two Hausa men from a neighboring village sold grilled meat at night. Young men often set up small stands in front of the gahawi and sold vegetables and cigarettes brought from El Obeid, the regional capital. Farmers sold watermelons. The stands were supplied by a Hausa man from Bireka who operated a fairly large store (also selling black market cigarettes and gasoline to lorry drivers and travelers), and an Um Belda man with a small tin shack, a kushk. A Hausa butcher slaughtered sheep, goats and occasionally cows every morning. An Arab from Bireka owned a small firewood bakery and supplied the stands with bread. A Burgo man with a donkey cart transported water from a well (about two kilometers away). Young men from all ethnic groups were hired by the women to build straw shelters (rakuba) and larger mud structures.

The young Burgo and Um Belda women who worked their tea stands earned income that was quite high by local standards. Some reported, in 1990, making profits of from LS 30 on a bad day up to LS 100 on a good day, a time when the average daily wage for agricultural labor was around LS 30. Most participated in a revolving savings fund with the other tea women. One woman with three shares in the fund took home LS 3600 in savings every two months. The women lived with their parents. In several cases, because these women had extensive working 
capital, they supported the entire family. In one family, a conflict emerged as to who would control the income from family agriculture. The daughter had hired the agricultural labor with her earnings from her tea-shop, so she expected to control the income even though her parents considered it family agriculture.

These intra-household conflicts over shares and control of income were, apparently, managed and kept under control because the size of the pie was large and expanding; perceptions were that participation in the roadside economy was a positive sum game. These perceptions were not shared by other actors. The 'government,' at the instigation of a faction of male Arab villagers, ordered the stands closed. The women were accused of being prostitutes, of selling prohibited local beer, and of not respecting the government. The government officials masked these concerns, in their official written documentation, with appeals to 'demarcation' and 'bringing order' to the market, and making women respect health ordinances.

Here is one young woman's account of the closure and destruction of the gahawi: ${ }^{10}$ The gahawi were first closed by the government in late 1991, it was the people of the People's Committee [village council]. They opened again in Ramadan [the spring of 1992]. The people who opened them were the Shabab al watun, the 'Youth of the Nation' organization [a radical youth group set up by the military regime], that was formed by Nuur el Din Mohamed from the market village. He held a big meeting with a microphone with about thirteen girls and thirteen boys. A lot of the Burgo girls were there. The Shabab opened the gahawi and said they would knock the police if they tried to stop them. 
But about ten girls were taken to the neighbouring market village, and spent the whole day in the 'prison' yard next to the police station. They were taken to El Obeid [the regional capital], and held outside the court. The police did not take them in, because they knew that they had no reason to close the gahawi in the first place. They brought the girls back. Those people are greedy. Later the girls opened them again for three months. As soon as the omda got power he closed them. And they kept them closed out of respect for the omda.

But until now they have no reason to have closed the gahawi. Why don't they close the gahawi in El Ibnoya [a road stop a few kilometers down the road]? Why not close them in the market village? They are all in the same administrative area. After the omda closed them people said they would go and make a formal complaint before the commissioner of the whole region of Kordofan, or go to the court. Anyway, when the Shabab reopened the stands the police came and wanted to hit them, but the Shabab said they were the government and they would hit the police. We had I.D. cards, we ourselves were the government.

When they closed the gahawi I and others went and complained that we were oppressed because we had borrowed in the morning and when they closed we could not pay back the loans, and some had debts of LS 5000 to the storekeeper, butcher, and baker. And the People's Committee said we had to swear on the Koran that this was true- which we did- and the government would repay all the outstanding loans- which they did not. 
After the Shabab al watun opened them and they were closed again about ten of the girls went to work under the trees near the road in Um Belda. But the omda again ordered them to stop. They took the girls to court and said they would fine them LS 300 or one month in prison. How could people pay that much? A delegation of women went to Kazgeil and made a lot of noise. The girls said they would not pay, they would go to prison. But the police brought them out. They were afraid to take them to the court in El Obeid. They gave twentyfive lashes to five girls.

By November of 1992 all the stands were closed, overgrown with weeds, clay walls tumbling down. Trucks drove past the roadside market, or stopped at other markets before and after the Um Belda/Bireka market. The women tea sellers lost much of their working capital, and the storekeepers and butchers and bakers lost all of their business.

The closing of the gahawi represented a struggle and defeat for the women of the villages. It did not matter so much that the men may not have wanted to intentionally harm them; rather, the norms of women's activities became the yardstick by which power was measured. The more the norms were upheld and enforced, the more everyone knew who was in control of the village. In the process women came to be prohibited from certain public economic activities. This process took place outside (without) the household. It could not be argued that the change reflected a strengthening of bargaining within the households of the village. Very clearly, women's activities at the roadside were highly lucrative, and many men would have gladly permitted their wives to continue working for a larger share of the profits. Indeed, if some men had decided to keep their 
wives at home or in the fields, the profits of other men who chose not to exercise their enhanced controls over women would have been even higher, as the 'rents' to be earned at the roadside would have been divided among fewer women.

The closing of the gahawi may well reflect similar changes in the structures of women's commercial activities in Sudan. Over the last decades, women have increasingly come to manage and control independent agricultural enterprises. While confirmation is not available due to the paucity of research as the country has descended into disorder and intensified civil war, it is reasonable to suppose that international and urban migration, and the ongoing civil war and military conscription have been responsible for this pattern. Ironically, the greater involvement of women in commercial activities may have raised their profiles, leading the military regime to adopt as a central policy and rhetorical plank a commitment to strengthening regulation of women's economic activities.

Activity-regulating norms in Burkina Faso

Norms regulating the activities of women in increasingly commercialized agriculture were also well in evidence in southwestern Burkina Faso. This was true of the majority Bwa ethnic group, as well as many other local groups and the fast-growing migrant community from the Mossi ethnic group. The setting for this study was the village of Bereba, roughly one hundred kilometers north-east of Bobo-Dioulasso (capital of Houet province). Bereba lay in the heart of Burkina Faso's cotton zone, a dynamic and expanding sector of the national economy. The center of the village was the old Bwa residential area that bordered a large seasonal stream, a bas fonds currently being developed for rice cultivation. On the southern edge of the Bwa village an 
enormous kapok tree shaded the market, held on Mondays and Fridays. Mossi migrants used to settle around the market, but in the past few decades the influx of migrants had led to settlements dispersed around the village. A census taken in 1994 listed 121 families (including several very large compounds of 40-50 people) with a total population of 1317 (up from 1193 in 1985 , according to the national census, an increase of only 10 percent over the decade). Two thirds of the households were Bwa, one third Mossi, and a scattering of Dafing, Djula, Samogo. The great majority of the Bwa adhered to the local Do religion, while the majority of Mossi were Muslim. About 100 villagers were Christian.

The village was very well developed in terms of using animal traction, fertilizer, pesticides and improved cotton and maize seed. There were few tractors, however, and many families still cultivated large areas by hand. Oxen were readily rented, though the price was high and timing was not always assured. Thus the village was typical of the entire area of southwestern Burkina, which had experienced rapid transformation as cultivation of cotton and adoption of mechanization was supported and subsidized.

Men and women in Bereba organized their lives in ways similar to the general descriptions of household relations in West Africa. Forced marriages and polygyny were common. Separate budgets and activities were common. Men owned most of the property and wealth, women complained that they were poorly compensated for their contributions to household production. In Bereba, gender inequality appeared to be more pronounced among the Mossi. There was a clear popular ranking: Bwa women were more 'free' than Mossi women. ${ }^{11}$ But the comparison was difficult to make. Both groups followed practices suggestive of unequal status. ${ }^{12}$ Bwa women were married through stylized 'kidnappings,' where the young man would steal his 
bride in the night. As long as he carried out the required three work parties on her parents fields, she was obligated to stay with him. There was considerable wife-beating, in part associated with the over-consumption of alcohol. Bwa women could not own land. They often married outside of their villages. An incident in 1996 suggested the force of norms regarding marriage and widowhood:

Bezoun met a woman named N'miegnidofini from Woro, whose husband had recently died. She was visiting a relative in Tui. They agreed to marry. She left for Woro to retrieve her belongings, but on the appointed day for them to meet Bezoun found himself confronted by three armed men claiming to be N'miegnidofini's brothers-in-law. They said she could not marry him, that she belonged to Woro, and she had to stay in their household. Bezoun fled, but the next day N'miegnidofini joined him. Soon therafter the brothers came to Tui and called all the women of Woro married in Tui. "You must return to Woro. Bezoun has no right to take N'miegnidofini, and if he insists on keeping her then we will insist that you come back to Woro, since you belong to Woro." Early the next morning eleven women met in a house outside of Tui, prepared with their small sacks to leave. Elders from Tui talked with the men from Woro, and with Bezoun, and with N'miegnidofini. Finally N'miegnidofini agreed to return to Woro. At twilight, the other women returned to their homes and families. 
Because N'miegnidofini's actions threatened inter-village relations, the men of Tui were willing to force eleven women — wives of their co-villagers — to return to Woro, leaving their children and hearths behind.

But Mossi women were perhaps in an even more disadvantageous position. They were much more 'submissive' in terms of personal, ritualized gestures towards men (such as kneeling with bowed head when talking with men). Some ventured into the market with great reluctance. Forced marriages were more common. Divorce very infrequent. Mossi marriages were more explicitly oriented towards creating family alliances in an uncertain environment; women were often spoken of as 'draft power'. Divorce among the Bwa was common, with women leaving their husband's quite often and quite easily. Women's rights to their children were stronger. Bwa girls were much more likely to go to school. Mossi women were prohibited from brewing beer even though many Mossi women in the provinces of origin made the Mossi equivalent, raan. Bwa women seemed to be discouraged from farming on their own, and almost none had personal fields.

In this atmosphere of a great multiplicity of gendered norms, there is also evidence of direct activity-regulating norms. The method here is to look for evidence of those norms by comparing the two ethnic groups, the Bwa and the Mossi, and show that the more patriarchal Mossi seemed to enforce norms that women work on the fields of their husbands. Bwa women, by contrast, seemed more free to allocate their time as they choose. One way to test the comparative restrictiveness of activity-regulating social norms is to examine data on the allocation of time. An implication of differences in restrictions is that the responsiveness of women, in terms of their allocation of time, to the capital of their husbands, should vary by ethnic group. If a 
woman was free to allocate her time, when her husband had more oxen she would be more likely to go and work with him. Her productivity on the farm would be high. If her husband had no oxen, she may well go off and work on another activity. Women who belong to ethnic groups that restrict women to work for their husbands will exhibit less responsiveness. Regardless of how many oxen their husbands' have, they are required to work on the 'family' fields controlled by the husbands.

Figure 3 shows that in Bereba village the Bwa women were much more responsive to the number of oxen owned by their husbands than were Mossi women. The data were collected from 109 women in the 1995 season. The women were asked every week how they had allocated their time for each day in the previous week. The figure shows the average percent of time worked by a woman according to how many oxen were owned by her husband. The first panel shows this average time for ordinary week days, the second panel shows the averages for the two market days of the village, when most men and women did not work in the fields. The figure shows that Mossi women almost always worked 20 percent of the time on the fields. Bwa women worked almost no time for their husbands when their husband's had no oxen. Regression analysis (reported in Kevane and Wydick 1997) confirms that this result is robust when controlling for other variables such as age, household wealth, education and children. This differential responsiveness is strongly suggestive of the existence of different norms regarding the appropriate allocation of women's time. Mossi women seem more constrained.

[Figure 3 about here]

Further evidence on these differences comes from the three years of data collected by the International Center for Research in the Semi-arid Tropics (ICRISAT) who followed Mossi and 
Bwa households from 1981 to 1983 in four villages close to Bereba. The ICRISAT survey collected data on the total amount of time devoted by men and women from a household to the 'family' fields controlled by the male household head. There were 77 Bwa or Mossi households. Figure 4 shows that when women were in households with more farm equipment, defined as households that had oxen and either plows or carts, they worked more on the fields of their husbands. Each bar shows the percent difference between the average hours worked by women on family fields in households with farm equipment and in households without farm equipment. The percent differences are high for Bwa women, for all three years, and low for Mossi women. Bwa women in households with more farm equipment worked significantly more than time than did Bwa women in households without capital. Mossi women in households with high farm equipment, by contrast, worked only slightly more than Mossi women in households with low farm capital. As if to confirm this description, Mossi men worked less when they had more capital, for two of the three years. (The results of 1983, a drought year, may be somewhat anomalous.) Bwa men always worked more when their households had more capital.

[Figure 4 about here]

\section{Conclusion}

The discussions of women's work in Sudan and Burkina Faso suggest that norms regulating the socially permissible economic activities of women are important. In Sudan, women were prohibited from earning high incomes in the tea stands at the roadside market. In Burkina Faso, women of the Mossi ethnic group appear to be constrained in their allocation of time, and 
are not able to follow their Bwa neighbors who earn higher incomes from brewing beer or other market work. These two examples confirm the effects of activity-regulating norms.

The problem is that much of the literature has come to focus on intra-household issues as the major research and policy arena of gender discussions. Research has helped the understanding how divergent preferences within households affect allocations of schooling, nutrition, calories, and consumption goods to boys and girls, as well as how credit programs for women affect their bargaining positions within households. Also a subject of research is how commercialization alters the threat points in household bargaining. By contrast, less research is devoted to understanding how public policy and economic change affects local norms that regulate the activities of women. Yet clearly this is a question of equal if not perhaps greater importance than shifts in intra-household bargaining power.

There is a striking contrast in the policies suggested by the two approaches. ${ }^{13}$ To take one example, the intra-household approach to women's credit programs and women's public works programs has argued that these may have detrimental unintended consequences (Goetz and Gupta 1996). A number of papers have argued that these programs induce women to devote extra hours to earning income under their control, because this strengthens their bargaining position within the household. But this extra labor time outside of the home comes at the expense, it is argued, of children's care time and nutrition. So the net positive effects of the programs may be marginal or even negative. The extra-household approach, however, would argue that policies and programs that change local norms may have very large favorable effects for women and children. 


\section{Endnotes}

*Research in Sudan was supported by a grant from the Collaborative Fulbright Program and the Mellon Fellowships Program. Research in Burkina Faso was funded by the West Africa Research Association and the Harvard Academy for International and Area Studies Program. I would like to gratefully acknowledge the generosity of all of these programs. Conversations with Leslie Gray and Bruce Wydick have been very helpful in stimulating my thinking on the issues discussed here. Permission to use the data from the ICRISAT survey was generously provided to me by the International Crops Research Institute for the Semi-Arid Tropics, Niamey, and Chris Udry was helpful in this regard.

1.See, for example, Bernal (1988), Besteman (1995), Davison (1988), Dey (1981), Diduk (1989), Hakansson (1986), Hemmings-Gapihan (1985).

2.Analysis of these determinants does not rule out the possibility that women are impoverished not because they are women, but rather because they happen to be relatively asset-less or skill-less in a changing economy. This latter kind of explanation would focus on why the poor become relatively poorer; the focus here is on why women might become relatively poorer. Fortman (1984) raises the possibility that there are no 'gender' distinctions made in the marketplace: the fact that female household heads are poorer than male heads accounts for their variable participation in factor markets.

3.See Katz (1991) and Koopman (1991). Agarwal (1994, 1997) has perhaps been the staunchest champion of the extra-household approach. In discussing the welfare implications of women's unequal access to resources, Agarwal has drawn attention to the processes of national and 
community rule-making. This rule-making or norm-making (in the case of more isolated village societies) may be formal (as laws, written contracts, parliamentary and regional decision-making body rules of procedure) or informal (one thinks of men's clubs, sanctions against public appearances and participation by women, codes of dress and marriage).

4.Wolf (1990) has made this point explicitly, in the context of factory work in Indonesia and Taiwan; see also Folbre (1984) and the papers in Dwyer and Bruce (1988).

5.While in the 1960s only $26 \%$ of women eloped, in the 1980s Hakansson found $87 \%$ eloped. Elopements and irregular unions that do not involve bridewealth payment have led to situations where wives are no longer necessarily absorbed into the patrilineal tenure system. These women can be expelled from a man's land easily. According to Hakansson (1986:10), "dissolution of informal unions are mostly initiated by men." This is not a phenomenon unique to Kenya. Andre and Platteau (1996:29) find, in their careful study of a Rwandan village, "roughly two-third of the couples in $\mathrm{N}$. have been married without inkwano [customary payment], and the proportion is obviously much higher among young couples."

6.Hale (1996:199) quotes a supporter of the NIF: "It is not that we forbid women to work. If she must work, then perhaps it is to the husband or to other male members of her family where we should look for any criticism. We only blame her if she goes to work as a frivolous act and does not behave appropriately in the workplace." The NIF strategy may simply represent an extension of northern Sudanese (Nile Valley) gender relations to the rest of the country (see Boddy 1985). See Kevane and Gray (1995) for more discussion.

7.Already in western Sudan there seemed to be clear evidence of a deepening feminization of poverty (Riely 1989). 
8.The word is derived from the Arabic root for coffee, gahwa. The singular for coffeehouse, in western Sudan, is also gahwa.

9.The letter was copied to the administrative officer (Dabit tanfizi) of El Obeid district, the police chief of Kazgeil (a large neighboring village), the omda of Kazgeil, the shiekh of Um Belda, and "Gahwa owners." The translation is by the author.

10.The text is from interview material recorded in Kevane (1993).

11.The whole idea of 'ranking' ethnic groups, and men and women, is fraught with troubling implications. First, there is considerable variation within groups, across villages, households and individuals. Second, men are equally subject to certain restrictive norms. Sometimes men are forced into marriages against their will. Sometimes they are required to support, or even 'marry', the widows of their deceased brothers. Sometimes a woman leaves her husband and children for months, with nary an excuse or apology. Third, discussions of women's status were often used in the colonial period as justifications for colonial rule (Labouret 1940). Just as in Sudan, discussions of gender risk being used as rhetorical devices favoring other less apparent interest groups.

12.The discussion that follows draws freely on Capron and Kohler (1978), Retel-Laurentin (1973), and Weidelener (1973).

13.Policies need not be coercive, or implemented by government. Indeed, they are often more likely to be successful when organized on a private, voluntary basis. 


\section{References Cited}

Akerlof, George, Yellen, Janet and Katz, Michael. 1996. An analysis of out-of-wedlock childbearing in the United States. Quarterly Journal of Economics 111:277-318

Akerlof, George. 1980. A Theory of Social Custom, of Which Unemployment May be One Consequence. Quarterly Journal of Economics 94:749-775.

Andre, Catherine, and Jean-Philippe Platteau. 1996. 'Land Tenure under Unendurable Stress: Rwanda Caught in the Malthusian Trap' Cahiers de la Faculté des Sciences Economiques et Sociales No. 164, Facultés Universitaires Notre-Dame de la Paix, Namur, Belgium.

Bassett, Thomas. 1988. Breaking Up the Bottlenecks in Food-Crop and Cotton Cultivation in Northern Cote d'Ivoire. Africa 58:147-173.

Bassett, Thomas. 1991. Migration et Féminisation de l"agriculture dans le nord de la Côte d'Ivoive in F. Gendreau, C. Meillassoux, B. Schlemer and M. Verlet, eds. Les Spectres de Malthus, pp. 219-45, Paris.

Becker, Gary. 1981. A Treatise on the Family Cambridge: Harvard University Press. 
Bernal, Victoria. 1988. Losing Ground- Women and Agriculture on Sudan's Irrigated Schemes:

Lessons from a Blue Nile Village in Jean Davison, ed., Agriculture. Women and Land: The African Experience, pp. 131-156, Boulder: Westview Press.

Besteman, Catherine. 1995. Polygyny, Women's Land Tenure, and the "Mother-Son Partnership" in Southern Somalia. Journal of Anthropological Research 51:193-213.

Boddy, Janice. 1985. Bucking the Agnatic System: Status and Strategies in Rural Northern Sudan in Judith Brown and Virginia Kerns, eds., In Her Prime: A New View of Middle-Aged Women, pp. 101-115, Mass.: Bergin \& Garvey Publishers.

Capron, Jean and Kohler, J.M. 1978. De quelques characteristiques de la pratique matrimoniale Mossi contemporaine in C. Oppong, G. Abada, M. Bekombo-Priso and J. Mogley, eds., Marriage, fertility and parenthood in West Africa Canberra: The Australian National University.

Carney, Judith, and Watts, Michael. 1990. Manufacturing Dissent: Work, Gender and the Politics of Meaning in a Peasant Society. Africa 60:207-241.

Carter, Michael, and Katz, Elizabeth. 1997. Separate Spheres and the Conjugal Contract: Understanding the Impact of Gender-Biased Development in Lawrence Haddad, John Hoddinott and Harold Alderman, eds. Intrahousehold Resource Allocation in Developing Countries, pp. 95-111, Baltimore, MD: The Johns Hopkins University Press. 
Dacher, Michele. 1992. Prix des Epouses, Valeur des Soeurs Paris: Editions L'Harmattan.

Davison, Jean. 1988. Who Owns What? Land Registration and Tensions in Gender Relations of Production in Kenya in Jean Davison, ed., Agriculture, Women and Land: The African Experience, pp. 157-76, Boulder: Westview Press .

Dey, Jennie. 1981. Gambian Women: Unequal Partners in Rice Development Projects? Journal of Development Studies 109-22.

Diduk, Susan. 1989. Women's Agricultural Production and Political Action in the Cameroon Grassfields. Africa 59: 338-355.

Dixon-Mueller, Ruth. 1985. Women's Work in Third World Agriculture. Geneva: International Labour Office.

Ensminger, Jean, and Knight, Jack. 1997. Changing Social Norms: Commoon Property, Bridewealth, and Clan Exogamy. Current Anthropology 38:1-24.

Folbre, Nancy. 1997. Gender Coalitions: Extrafamily Influences on Intrafamily Inequality in L. Haddad, J. Hoddinott and H. Alderman, eds., Intrahousehold Resource Allocation in Developing Countries, pp. 263-74, Baltimore, MD: The Johns Hopkins University Press. 
Folbre, Nancy. 1986. Cleaning House: New Perspectives on Households and Economic

Development. Journal of Development Economics 21: 5-40.

Fortman, Louise. 1984. Economic Status and Women's Participation in Agriculture: A Botswana Case Study. Rural Sociology 49:452-64.

Goetz, Anne Marie, and Gupta, Rina Sen. 1996. Who takes the credit? Gender, power, and control over loan use in rural credit programs in Bangladesh. World Development 24:45-64.

Gray, Leslie, and Kevane, Michael. 1993. For Whom Is the Rural Economy Resilient? Initial Effects of Drought in Western Sudan. Development and Change 24:159-76.

Grundfest Schoepf, Brooke. 1985. The 'Wild', the 'Lazy' and the 'Matriarchal': Nutrition and Cultural Survival in the Zairian Copperbelt. Working paper \#96, Office of Women in International Development, Michigan State University.

Haddad, Lawrence, Hoddinott, John and Alderman, Harold. eds. 1997. Intrahousehold Resource Allocation in Developing Countries Washington, D.C.: Johns Hopkins University Press.

Hakansson, Thomas. 1986. Landless Gusii Women: A Result of Customary Land Law and Modern Marriage Patterns. Working Papers in African Studies, African Studies Programme: Department of Cultural Anthropology, University of Uppsala. 
Hemmings-Gapihan, Grace Salome. 1985. Women and economy in Gourma, 1919-1978: A study of economics change in Bourkina Fasso (Upper Volta). Ph.D. Dissertation, Yale University.

Hill, Polly. 1969. Hidden Trade in Hausaland. Man 4:392-409.

Hodgson, Dorothy, and McCurdy, Sheryl. 1996. Wayward Wives, Misfit Mothers, and Disobedient Daughters: Wicked Women and the Reconfiguration of Gender in Africa. Canadian Journal of African Studies 30:1-9.

Hunt, Nancy. 1991. Noise over camouflaged polygamy: Colonial morality, taxation and a woman-naming crisis in Belgian Africa. Journal of African History 32:471-95.

Jones, Christine. 1986. Intra-Household Bargaining in Response to the Introduction of New Crops: A Case Study from North Cameroon in Moock, Joyce, ed., Understanding Africa's Rural Households and Farming Systems, pp. 105-123, Boulder: Westview Press.

Katz, Elizabeth. 1991. Breaking the myth of harmony: Theoretical and methodological guidelines to the study of rural Third World households. Review of Radical Political Economics $23: 37-56$ 
Kevane, Michael. 1994. Village Labor Markets in Sheikan District, Sudan World Development 22:839-57.

Kevane, Michael, and Gray, Leslie. 1995. Local politics in the time of Turabi's revolution: gender, class and ethnicity in western Sudan. Africa 65: 271-97.

Kevane, Michael, and Wydick, Bruce. 1997. Social Norms and the Time Allocation of Women in Southwestern Burkina Faso. Mimeo, Dept. of Economics, Santa Clara University.

Koopman, Jeanne. 1991. Neoclassical household models and modes of household production: Problems in the analysis of African Agricultural households. Review of Radical Political Economics 23:148-73.

Kursany, Ibrahim. 1983. Peasants of the Nuba Mountains Region Review of African Political Economy 35-44.

Labouret, Henri. 1940. Situation matérielle, morale et coutumière de la femme dans l'OuestAfricain. Africa 13:97-124.

Mintz, Sidney. 1971. Men, Women, and Trade. Comparative Studies in Society and History 3:247-69. 
Obbo, Christine. 1976. Dominant Male Ideology and Female Options: Three East African Case Studies. Africa 46:371-89.

Quisumbing, Agnes. 1996. Male-Female Differences in Agricultural Productivity: Methodological Issues and Empirical Evidence. World Development 24:1579-95.

Ram, Rati and Singh, Ram. 1988. Farm Households in rural Burkina Faso: Some evidence on allocative and direct return to schooling, and male-female productivity differentials. World Development 16:419-24.

Retel-Laurentin, Anne. 1973. Evasions féminines dans la Volta noire. Cahiers d'Etudes africaines 19:253-298.

Riely, Frank. 1991. Drought Responses of the Kababish Pastoralists in Northern Kordofan, Sudan: Implications for Famine Early Warning. Unpublished manuscript, Rome: F.A.O.

Roberts, Penelope. 1988. Rural Women's Access to labor in West Africa. in Sharon Stichter and Jane Parpart, eds., Patriarchy and Class: African women in the home and the workforce, pp. 97114, Boulder:Westview Press. 
Roberts, Richard. 1984. Women's Work and Women's property: Household Social Relations in the Maraka Textile Industry of the Nineteenth Century. Comparative Studies in Society and History 229-50.

Saul, Mahir. 1981. Beer, Sorghum and Women's Production for the Market in Rural Upper Volta Africa 51:746-64.

Saul, Mahir. 1989. Separateness and Relation: Autonomous Income and Negotiation Among Rural Bobo Women in Richard Wilk, ed., The Household Economy: Reconsidering the Domestic Mode of Production, pp. 171-93, Boulder: Westview Press.

Solivetti, Luigi. 1994. Family, Marriage and Divorce in a Hausa Community: A Sociological Model Africa 64:255-71.

Sultan Dawood. 1993. Merchants and a Bankrupt State: Reflections on Contextual Imperatives and the Genesis of Predicament in Kordofan African Studies Review 36:75-94.

Tully, Dennis. 1988. Culture and Context in Sudan: The Process of Market Incorporation in Dar Masalit Albany, NY: State University of New York Press.

Turittin, Jane. 1988. Men, Women and Market Trade in Rural Mali, West Africa. Canadian Journal of African Studies 22:583-604. 
Udry, Christopher. 1996. Gender, Agricultural Production and the Theory of the Household. Journal of Political Economy 104:1010-47.

von Bulow, Dorthe. 1992. Bigger than Men? Gender Relations and Their Changing Meaning in Kipsigis Society, Kenya. Africa 62:523-46.

von Braun, Joachim, and Webb, Patrick. 1989. The Impact of New Crop Technology on the Agricultural Division of Labor in a West African Setting. Economic Development and Cultural Change, 37:513-34.

Weidelener, Anne. 1973. Reflexions sur le mariage en pays mossi. Institut superieur de culture religieuse Memoire - ISCR. Abidjan : ISCR.

Young, H. Peyton. 1998. Individual Strategy and Social Structure. Princeton, N.J.: Princeton University Press. 
Figure 1: How commercialization affects actions and welfare of men and women

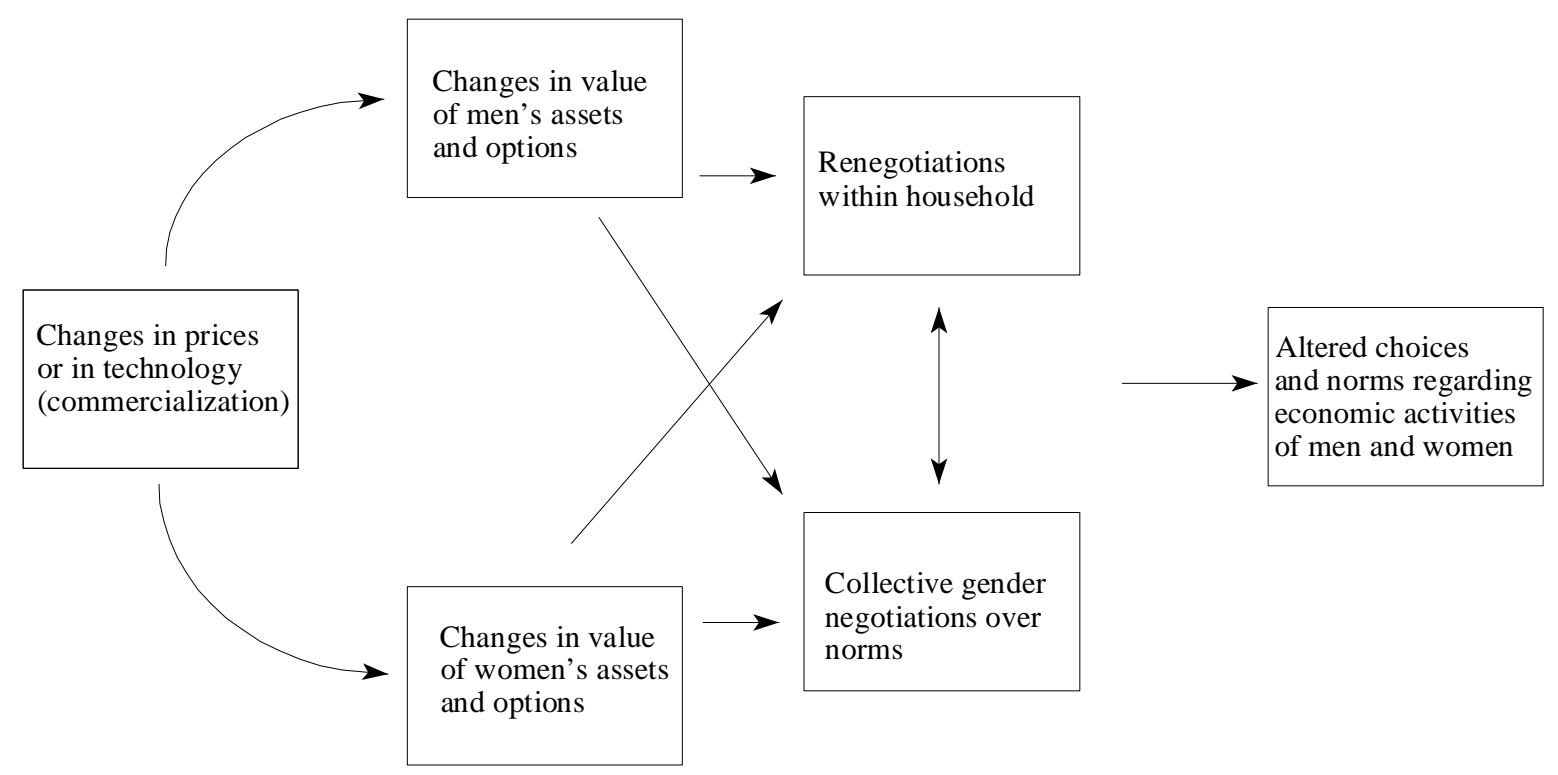

Source: Author 
Figure 2: Decision tree for marriage offers by men and acceptances by women

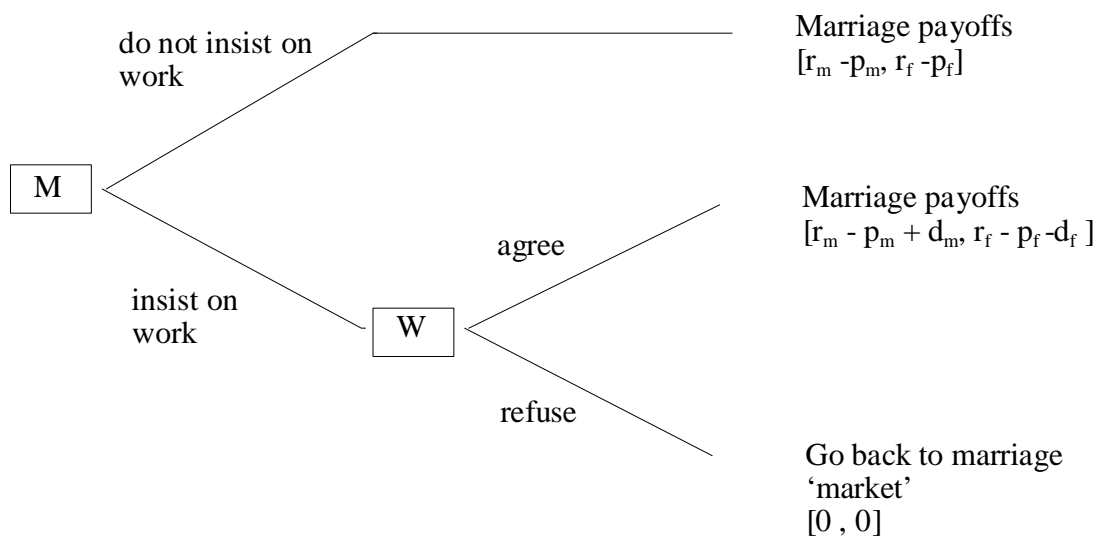

$\mathrm{M}=$ man makes first move

$\mathrm{W}=$ woman makes second decision

Source: Modified from Akerlof, Yellen and Katz (1996) 
Figure 3: Average time women spent on fields of husband, according to husband's oxen

Time on husband's field (market days) (according to oxen owned by husband)

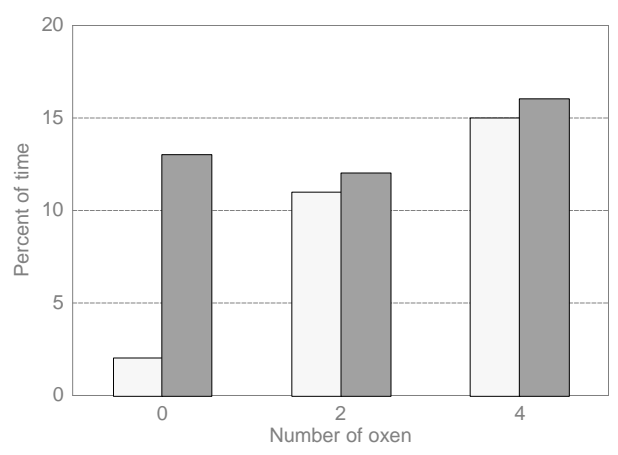

Time on husband's field (week days) (according to oxen owned by husband)

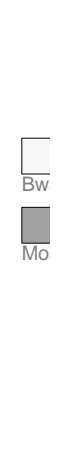

Source: Author survey, 1995 